\title{
Uzbekistan's Trade Policy Liberalization. Predicted Impact of WTO Accession on Chemical Industry Trade
}

\author{
Lea Melnikovová ${ }^{1}$, Shukhrat Shadmanov ${ }^{2}$, Sergey Voronin $^{3}$, Bobur Qoraboev $^{4}$ \\ ${ }^{1}$ Department of International Business, Metropolitan University Prague, \\ Prague 10000, Czech Republic \\ 2 School of Business and Management, Management Development Institute \\ of Singapore in Tashkent, Tashkent 100185, Uzbekistan \\ ${ }^{3}$ Department of Finance and Credit, Tashkent Branch of Plekhanov Russian \\ University of Economics, Tashkent 100164, Uzbekistan \\ ${ }^{4}$ Department of Improvement Taxes and Customs Tariff Policy, Institute for \\ Fiscal Studies under the Ministry of Finance of the Republic of Uzbekistan, \\ Tashkent 100052, Uzbekistan

\footnotetext{
1 lea.melnikovova@mup.cz, https://orcid.org/0000-0003-0283-8483

${ }^{2}$ shshadmanov@mdis.uz, https://orcid.org/0000-0002-0324-6247

${ }^{3}$ Sergey_voronin63@yahoo.com, https://orcid.org/0000-0003-2288-8365

${ }^{4}$ BKoraboev@ifs.mf.uz, https://orcid.org/0000-0003-4051-982X
}

\begin{abstract}
This paper is dedicated to the recent reforms in Uzbekistan's foreign trade policy and the process of the country's accession to the World Trade Organization. It pays special attention to the chemical industry trade; with the partial equilibrium model employed, expected changes in imports of chemicals, budget revenues and consumer welfare are revealed. Two scenarios - mere tariff reduction or abolition of country-specific discrimination practices in imports - are considered. Results show that, in the former case, imports of chemical products and consumer welfare will slightly increase and budget revenues will decline; the outcome in the latter case differs: budget revenues will grow considerably, whereas imports and consumer welfare will decrease. We conclude in the latter case that the negative effect will be outweighed by creating a fairer, more competitive environment thanks to removing discrimination practices such as import-specific excise taxes and exemptions on import duty payments for state companies.
\end{abstract}

Keywords: World Trade Organization, free trade agreements, Harmonized System classification, most favoured nation, chemicals and allied industries, partial equilibrium model, tariff revenues, consumer welfare

JEL: E21, F13, F14, F15, F17

For citation: Melnikovová L., Shadmanov Sh., Voronin S., Qoraboev B. Uzbekistan's Trade Policy Liberalization. Predicted Impact of WTO Accession on Chemical Industry Trade. Financial Journal, 2022, vol. 14, no. 1, pp. 39-55.

https://doi.org/10.31107/2075-1990-2022-1-39-55.

(C) Melnikovová L., Shadmanov Sh., Voronin S., Qoraboev B., 2022 


\section{INTRODUCTION}

Uzbekistan has undergone massive changes since the new president, Shavkat Mirziyoyev, took office in 2016. The country has embarked on a reform journey and the economy has experienced unprecedented changes. Uzbekistan's trade policy has been subject to reforms concerning, particularly, customs fees and procedures in order to lower tariff barriers and simplify customs formalities. Uzbekistan has recently resumed its negotiations with the World Trade Organization (WTO) ${ }^{1}$. As a country outside the organization, Uzbekistan can modify its trade policy more independently, but with regard to the ongoing negotiations any future changes should reflect WTO requirements. Uzbekistan takes part in the Global Trade Facilitation Programme of the World Customs Organization (WCO), which is a four-year program (2018-2022) aiming, among other things, to facilitate the adoption of international standards and best practices for international trade in the participating countries ${ }^{2}$. Uzbekistan has also been debating with the Eurasian Economic Union (EAEU) on mutual collaboration and strengthening their relationship. Members of the EAEU are Uzbekistan's important trading partners - they account for almost $29 \%$ of the country's trade turnover ${ }^{3}$. Uzbekistan was granted an observer status in the EAEU in December $2020^{4}$. Uzbekistan is a member of the Commonwealth of Independent States Free Trade Area (CISFTA) comprising of Russia, Belarus, Ukraine, Kazakhstan, Armenia, Moldova, Kyrgyzstan and Tajikistan; therefore, no import tariffs are applied to import of goods originating from the CISFTA countries with some exceptions $^{5}$. Uzbekistan has also concluded free trade agreements (FTAs) with Azerbaijan, Turkmenistan and Georgia ${ }^{6}$.

Uzbekistan has granted the most favored nation (MFN) regime to 47 countries, especially its large trading partners including the European Union member countries ${ }^{7}$. The EU is Uzbekistan's major trading partner, which is also reflected in the formalized relationship with the Union. The Partnership and Cooperation Agreement (PCA) with the EU has been in force since 1999, and Uzbekistan is currently negotiating the Enhanced Partnership and Cooperation Agreement (EPCA); these negotiations started in July $2018^{8}$. The current agreement provides for economic cooperation while ensuring that Uzbekistan's foreign trade practices comply with the rules of the WTO'. In November 2020 the European Commission decided to grant Uzbekistan the status of a beneficiary of the Generalized System of Preferences Plus

\footnotetext{
1 Uzbekistan resumes WTO membership negotiations. WTO, July 7, 2020. Available at: https://www.wto.org/ english/news_e/news20_e/acc_uzb_07jul20_e.htm.

2 SECO-WCO Global Trade Facilitation Programme. World Customs Organization, September 14, 2020. Available at: http://www.wcoomd.org/en/topics/capacity-building/activities-and-programmes/cooperation-programmes/ seco_wco-gtfp.aspx.

${ }^{3}$ Foreign economic activity - Merchandise trade. State Committee of the Republic of Uzbekistan on Statistics, accessed June 23, 2020. Available at: https://stat.uz/en/official-statistics/merchandise-trade.

${ }^{4}$ Uzbekistan gets observer status in Eurasian Economic Union. The Tashkent Times, last modified. December 11, 2020. Available at: https://tashkenttimes.uz/national/6054-uzbekistan-gets-observer-status-in-eurasianeconomic-union.

${ }^{5}$ Free trade agreements: CIS member states. Ministry of Economic Development of the Russian Federation, accessed February 23, 2021. Available at: https://www.economy.gov.ru/material/departments/d11/soglasheniya_ o_svobodnoy_torgovle/gosudarstva_uchastniki_sng/.

${ }^{6}$ List of countries granted the MFN regime and the free trade regime partner. National legislation database of the Republic of Uzbekistan. June 20, 2020. Available at: https://lex.uz/docs/4911947.

${ }^{7}$ List of countries granted the MFN regime and the free trade regime partner. National legislation database of the Republic of Uzbekistan.

8 Uzbekistan: EU to open negotiations on new comprehensive agreement. European Council. July 16, 2018. Available at: https://www.consilium.europa.eu/en/press/press-releases/2018/07/16/uzbekistan-eu-to-opennegotiations-on-new-comprehensive-agreement/.

9 EU-Uzbekistan relations. European External Action Service. November 12, 2018. Available at: https://eeas. europa.eu/headquarters/headquarters-homepage_en/11047/EU-Uzbekistan\%2Orelations.
} 
(GSP+) ahead of schedule. After the approval by the European Council and the European Parliament, this will allow the country to double the number of goods supplied duty-free to the European Union. In April 2021, the EU has accepted Uzbekistan as the 9th beneficiary country of the GSP+ and started applying preferential tariffs for products imported from Uzbekistan under this arrangement from 10 April $2021^{10}$.

In July 2020 Uzbekistan resumed the negotiations on accession to the WTO ${ }^{11}$. WTO membership is currently an important issue, and its benefits and challenges are being vividly discussed in the country since further liberalization steps will have to take place. Authors of empirical literature have come to ambiguous conclusions concerning the positive effects of WTO membership on trade flows. This raises questions whether the tariff reduction promoted by the WTO and its predecessor, the General Agreement on Tariff and Trade (GATT), has had desired results.

According to Rose, the WTO does not seem to have had much impact on trade; his conclusions are based on the standard gravity model of bilateral trade [Rose A.K., 2004]. He brings forward two explanations regarding WTO membership's little effect on trade. Firstly, the GATT/WTO has not forced most countries to reduce trade barriers, which is typical mainly for developing countries that have received special treatment. And secondly, WTO members often extend MFN status unilaterally to non-member countries, although they are not obliged to by WTO rules. The author concludes that WTO membership has a negligible effect on trade policy and therefore also on trade flows [Rose A.K., 2004]. However, he does not claim that the existence of GATT and the WTO has been irrelevant [Rose A.K., 2010]. He admits that WTO membership encourages creating trade links that may not exist otherwise.

Other authors are less critical. Subramanian and Wei are of opposite opinion to Rose; they found that the WTO has had a strong positive impact on trade, which has, however, been uneven [Subramanian A., Wei Shang-Jin, 2007]. They argue that the WTO promotes trade mainly for industrialized countries. Nevertheless, they admit that developing countries experience benefits as well, which are demonstrated in increased exports. Allee and Scalera argue that the more demanding a country's accession to an international organization is and the more substantial policy change is required to become a member, the more considerable are the benefits it will receive from membership [Allee T.L., Scalera J.E., 2012]. Eicher and Henn find that countries with greater stimulus to negotiate tariff reductions during the WTO accession process experience positive and substantial WTO trade effects [Eicher T.S., Henn C., 2011]. Dutt finds evidence for strong WTO effects, where the strongest ones are for developing countries that experienced a demanding accession process to join the WTO [Dutt P., 2020].

Pomfret has elaborated a study where he identifies the barriers to completing Uzbekistan's WTO accession negotiations, and the benefits and costs of WTO membership. He claims that the government's commitment to economic reform is key to the eventual membership [Pomfret R., 2020]. A sector-specific study examining the economic implications of WTO membership on Uzbekistan's highly protected automobile industry has been done by Umirdinov and Turakulov. The authors assume that the sector will have to deal with extreme pressures from internal and external players that will have immense consequences. In order to mitigate them, they suggest that an extended phase-out period for adjusting country's automobile industrial policy to WTO agreements be required, and the state should decrease its support to the auto industry gradually [Umirdinov A., Turakulov V., 2019].

\footnotetext{
${ }^{10}$ Uzbekistan joins EU's GSP+ arrangement. European Commission, 09.04.2021. Available at: https://trade. ec.europa.eu/doclib/press/index.cfm?id=2263, accessed 18.09.2021.

${ }^{11}$ Uzbekistan resumes WTO membership negotiations. WTO, 2020.
} 
Uzbekistan had undertaken the first reforms before the WTO accession process was resumed. In the past, the import regime of Uzbekistan was characterized by a high level of protectionism, and at the same time a large number of individual privileges regarding the payment of import fees were provided (hereinafter referred to as exemptions). Since 2017, important changes have taken place in this area aimed at liberalizing the foreign trade regime. Many protectionist measures persist, however.

The objective of this paper is to reveal the changes in Uzbekistan's foreign trade policy as well as its exports and imports, and to evaluate the impact of the possible WTO membership on trade in chemical products.

\section{STRUCTURE AND METHODS}

The paper is structured into two main parts. First, we analyze changes in the national legislation in recent years, especially the exchange rate policy liberalization, changes in import tariffs and import excise taxes that influence the eventual costs of import. We highlight the most important changes and look into subsequent changes in the country's foreign trade - both import and export - based on the latest data provided by the International Trade Centre (ITC) and the State Committee of the Republic of Uzbekistan on Statistics. In the following part, special attention is paid to Uzbekistan's chemical industry and the impact of the possible WTO membership on chemical products imports, budget revenues and consumer welfare. We use the partial equilibrium model employing the SMART partial equilibrium modeling tool. It uses indicators of elasticity of demand for imports, elasticity of export supply and elasticity of substitution on the basis of the World International Trade Solutions ${ }^{12}$ and estimations by [Hertel T. et al., 2007]. We work with two scenarios. Scenario 1 only considers changes in tariff rates. We assume that the import tariff rates in Uzbekistan will be reduced to the level of the neighboring countries' rates. Scenario 2 considers wider changes: we assume that Uzbekistan, along with the import tariff reduction, will abolish all discriminative practices in import. The two scenarios are explained in detail below. We observe changes for four groups of countries: (1) MFN countries according to Uzbekistan's agreements mentioned in the Introduction (47 countries); (2) CISFTA countries (10 countries); (3) nonMFN, non-CISFTA but WTO member countries; and (4) non-MFN, non-CISFTA and non-WTO countries. We calculate the change in imports of each group, changes in budget revenues and consumer welfare.

\section{RESULTS}

\section{Trade policy liberalization}

Fundamental changes in the national legislation have taken place in the past four years. The key legal document is the Customs Code, which regulates the movement of goods across the customs borders of the country, customs clearance, customs control, collection and payment of customs payments, and customs legislation violations procedures ${ }^{13}$. The new version of the Customs Code is under way and was open for public discussion online from August 17 to September 1, 2019 ${ }^{14}$.

\footnotetext{
${ }^{12}$ SMART Simulation Tool. World Integrated Trade Solution, 2020. Available at: https://wits.worldbank.org/ simulationtool.html.

${ }^{13}$ Customs Code of the Republic of Uzbekistan. National legislation database of the Republic of Uzbekistan, last modified January 20, 2016. Available at: https://lex.uz/docs/2876352.

${ }^{14}$ Customs Code of the Republic of Uzbekistan (new edition). Website for discussion of draft laws, accessed July 15, 2020. Available at: https://regulation.gov.uz/ru/document/6485.
} 
A measure of particular importance was the introduction of the current account convertibility in $2017^{15}$. In the same year, the government adopted a decision to significantly reduce customs duties for a long list of items. The presidential resolution "On measures to further streamline foreign economic activity and improve the system of customs and tariff regulation of the Republic of Uzbekistan" from June 2018 further and substantially reduced not only the custom tariffs on imported goods but also the excise tax on imports ${ }^{16}$. Also, the customs tariff rates have been unified for items similar in type, properties and utilization ${ }^{17}$. In December 2018 , some of the rates were increased again, e.g. for clothes, shoes, furniture, certain foods etc. ${ }^{18}$ High rates (40-70 \%) remain for vehicles ${ }^{19}$.

Tariffs are not the only cost of imports. Import excise taxes, value added tax (VAT) and customs clearance fees have to be considered as well. Import excise tax rates and the list of imported excisable products were subject to fundamental changes, too. Their importance has decreased but they are still an important tool for regulating imports and a source of budget revenues. Many goods are excisable only when they are imported in Uzbekistan, and are not subject to excise taxes if produced domestically ${ }^{20}$.

Import and export customs procedures have been simplified significantly, which received a positive response from the World Bank ${ }^{21}$, and exporters have been provided with state support concerning customs clearance formalities. To better understand the changes in ease of trading across borders as a result of simplification of the customs procedures, one can refer to the World Bank's Ease of Doing Business score for useful information. It "records the time and cost associated with the logistical process of exporting and importing goods and it measures the time and cost (excluding tariffs) associated with three sets of procedures - documentary compliance, border compliance and domestic transport"22. Despite recent improvements, Uzbekistan's performance is still not satisfactory - way under the regional average. In 2020, the country ranked 152 out of 190, while Kazakhstan ranked 105 and Russia 99. However, better performance was evident since Uzbekistan ranked 165 a year before.

Figures 1 and 2 show that the liberalization efforts had evident outcomes demonstrated by increased trade flows, especially imports. Reducing the customs tariffs and excise tax has resulted in larger imports values in 2018 and 2019. Uzbekistan experiences a trade deficit which has deepened in recent years ${ }^{23}$.

${ }^{15}$ Decree of the President of the Republic of Uzbekistan "On priority measures for the liberalization of foreign exchange policy". National legislation database of the Republic of Uzbekistan, last modified September 2, 2017. Available at: https://lex.uz/docs/3326423.

${ }^{16}$ Resolution of the President of the Republic of Uzbekistan "On measures to further streamline foreign economic activity and improve the system of customs and tariff regulation of the Republic of Uzbekistan." National legislation database of the Republic of Uzbekistan, last modified June 29, 2018. Available at: https://lex.uz/docs/3802366.

${ }^{17}$ Nearly 45\% of import fees to be reduced. Norma, April 13, 2018. Available at: https://www.norma.uz/nashi_ obzori/pochti_45_procentov_stavok_importnyh_poshlin_predlagaetsya_snizit.

${ }^{18}$ Comparative table of tariff rates according to PP-3818 dated Jun 29, 2018, changed under PP-4086 dated Dec 26, 2018. Norma. January 5, 2019. Available at: https://www.norma.uz/raznoe/sravnitelnaya_tablica_stavok_ importnyh_tamojennyh_poshlin_izmenivshihsya_soglasno_pp-4086_ot_26_12_2018_goda.

${ }^{19}$ Nearly $45 \%$ of import fees to be reduced. Norma, April 13, 2018.

${ }^{20}$ Law of the Republic of Uzbekistan on the State Budget of the Republic of Uzbekistan for 2020. Appendix 8. Rates of excise tax on excisable goods (services) produced (rendered) in the Republic of Uzbekistan. National legislation database of the Republic of Uzbekistan. December 9, 2019. Available at: https://lex.uz/docs/ 4635018\#4637054; Excise tax rates on excisable goods imported into the territory of the Republic of Uzbekistan. Complete legislation of Uzbekistan, June 29, 2018. Available at: https://nrm.uz/contentf?doc=548595_stavki_ akciznogo_naloga_na_podakciznye_tovary_zavozimye_na_territoriyu_respubliki_uzbekistan_(prilojenie_n_2_k_ postanovleniyu_prezidenta_ruz_ot_29_06_2018_g_n_pp-3818)\&products=1_vse_zakonodatelstvo_uzbekistana.

${ }^{21}$ Doing Business 2020: Uzbekistan. World Bank Group, February 14, 2020. Available at: https://www. doingbusiness.org/en/data/exploreeconomies/uzbekistan.

${ }_{22}^{2}$ Doing Business 2020: Uzbekistan.

${ }^{23}$ Foreign economic activity - Merchandise trade. State Committee of the Republic of Uzbekistan on Statistics. 


\section{Commodity structure of Uzbekistan's imports 2015-2019,} Harmonized System (HS) classification; mil. USD

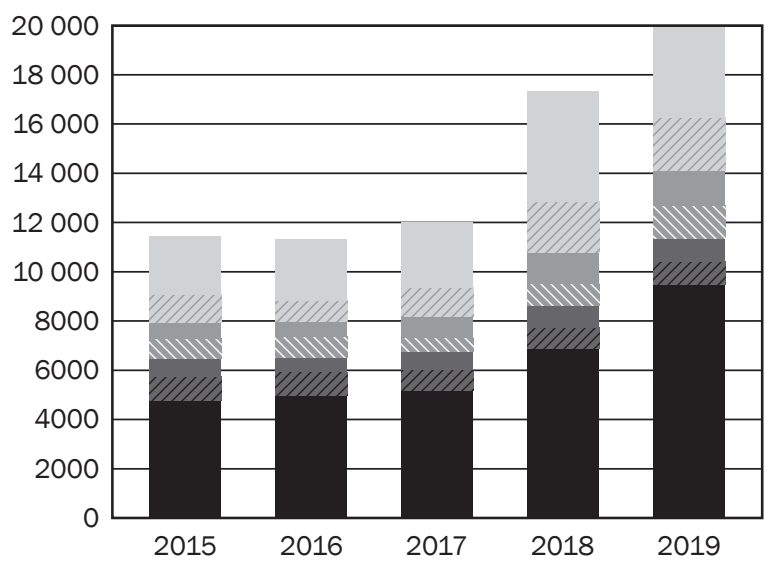

84 - Nuclear reactors, machinery and mechanical appliances; parts thereof 87 - Vehicles; other than railway WII or tramway rolling stock, and parts and accessories thereof

72 - Iron and steel 85 - Electrical machinery and equipment and parts thereof; sound recorders

IIv and reproducers; television image and sound recorders and reproducers, parts and accessories of such articles 27 - Mineral fuels, mineral oils

and products of their distillation; bituminous substances; mineral waxes

WIA 30 - Pharmaceutical products

2015

2016

2017

2019

Source: Foreign economic activity - Merchandise trade. State Committee of the Republic of Uzbekistan on Statistics.

The export value grew (Figure 2) partly because of gold exports. Uzbekistan is one of the top exporters of precious metals. In 2019 they accounted for almost a third of the country's exports $(29.8 \%)^{24}$. Other main export items remain more or less unchanged: fuels, cotton, copper, food products, plastics, clothing, and chemical products.

Figure 2

\section{Commodity structure of exports 2015-2019, HS classification; mil. USD}

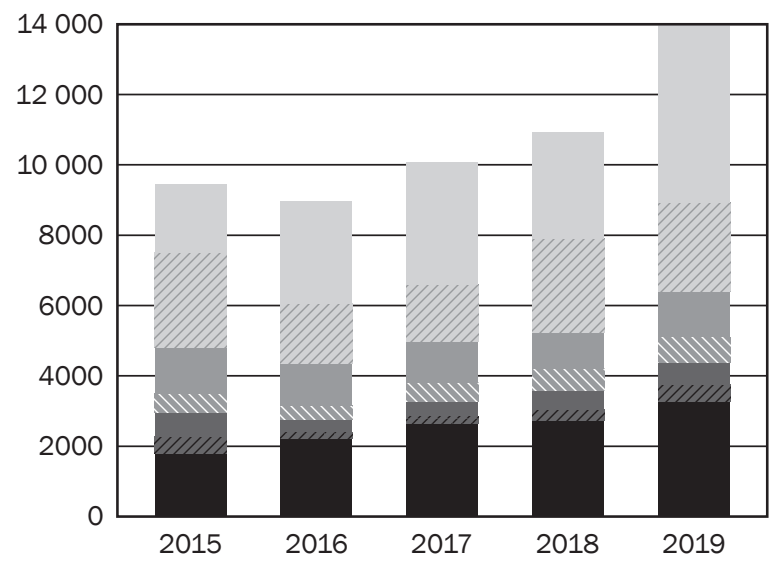

71 - Natural, cultured pearls; precious, semi-precious stones; precious metals, metals clad with precious metal, and articles thereof; imitation jewellery; coin

27 - Mineral fuels, mineral oils

III and products of their distillation; bituminous substances; mineral waxes

$52-$ Cotton

Anv 74 - Copper and articles thereof

08 - Fruit and nuts, edible;

peel of citrus fruit or melons

07 - Vegetables and certain roots and tubers; edible

other

Source: Foreign economic activity - Merchandise trade. State Committee of the Republic of Uzbekistan on Statistics.

\section{Impact of WTO accession on chemical industry trade}

Uzbekistan's production of nitrogen, phosphorus and potassium is ranked 8th in the world. In terms of volume and types of nitrogen and phosphorus fertilizers produced, the country occupies a leading position in the Central Asian region. Chemical products are exported to

${ }^{24}$ Uzbekistan exports over $\$ 1$ billion worth of gold in Q1. The Tashkent Times, April 23, 2020. Available at: https://tashkenttimes.uz/economy/5205-uzbekistan-exports-over-1-billion-worth-of-gold-in-q1. 
more than 30 countries around the world. The main export markets are traditionally the neighboring countries, such as Kazakhstan, Tajikistan, Kyrgyzstan and Afghanistan, but new ones are being explored, such as South Korea, Japan and others.

Uzbekistan's chemical industry has a significant potential in production thanks to the locally available raw materials, technical base and labor force, and represents one of the top industrial sectors of the economy. Raw materials that are important for the industry are natural gas, ammonia, nitric acid, industrial salt, limestone and industrial sulfur, all of them available in Uzbekistan. The availability of natural resources is a key advantage in an industry where raw materials and utilities account for between $40 \%$ and $90 \%$ of production costs [World Bank Group, International Finance Corporation, 2018]. With such unique advantages, Uzbekistan could become a net exporter of chemical products.

However, the high level of physical and moral depreciation of Uzbekistan's production facilities has reduced productivity and increased energy and material consumption of production over the past years, which is the main factor holding back the development of the chemical industry. The measures taken in recent years have been insufficient to improve the technical condition of the production facilities and increase their competitiveness in the global market [Mukhamedov D., Shipkova O., 2017].

Today, imports of chemical products are five times higher than exports ${ }^{25}$. The main volume of production is focused on meeting the needs of the domestic market. Real growth rates of production have significant fluctuations, and the share of chemical industry in the industrial sector has been decreasing; see Table 1.

Table 1

Key indicators of the chemical industry in Uzbekistan

\begin{tabular}{|l|c|c|c|c|c|}
\hline & 2015 & 2016 & 2017 & 2018 & 2019 \\
\hline Production (mil. USD) & $1,944.6$ & $2,488.4$ & $1,934.7$ & $1,868.5$ & $2,147.3$ \\
\hline Import* (mil. USD) & 558.4 & 579.6 & 630.7 & 777.5 & $1,081.8$ \\
\hline Export* (mil. USD) & 234.6 & 188.0 & 245.7 & 217.2 & 208.5 \\
\hline Production growth (\% to the previous year) & 110.4 & 138.3 & 101.7 & 99.1 & 102.3 \\
\hline Share in the industrial sector (\%) & 6.5 & 8.2 & 8.4 & 8.0 & 5.9 \\
\hline Number of employees in the industry & 41,797 & 42,499 & 45,986 & 46,721 & 47,085 \\
\hline
\end{tabular}

Source: Industry. State Committee of the Republic of Uzbekistan on Statistics, accessed September 12, 2020 (https://stat.uz/en/official-statistics/industry).

Due to the developed agricultural sector in Uzbekistan, the dominant position in the structure of the chemical industry is the production of fertilizers for agriculture. Agricultural chemistry practically meets the needs of the republic's cotton and grain cultivation ${ }^{26}$.

The share of imports in the total market for chemical products in Uzbekistan is $30.3 \%$, and the share of local production is $69.7 \%{ }^{27}$. As mentioned above, local production is mainly concentrated in the production of fertilizers; this is the only product group where Uzbekistan is a net exporter. For other groups of goods, Uzbekistan is a net importer. Products such as pesticides and herbicides for agriculture and chemicals for rapidly developing industries such as textiles, leather and food production are mainly imported ${ }^{28}$. We can expect further growth in imports due to the fast growth of the textile, leather and food industries, as domestic production is not well developed.

\footnotetext{
${ }^{25}$ Foreign economic activity - Merchandise trade. State Committee of the Republic of Uzbekistan on Statistics.

${ }^{26}$ Creating markets in Uzbekistan: from stabilization to competitiveness. International Finance Corporation.

${ }^{27}$ ITC Trade Map. International Trade Centre, no. 15, 2020. Available at: https://www.trademap.org/; Foreign economic activity - Merchandise trade. State Committee of the Republic of Uzbekistan on Statistics.

${ }^{28}$ ITC Trade Map. International Trade Centre.
} 
The main import items are other chemicals (HS2 code 38); organic chemicals (HS2 code 29); tanning or dyeing extracts; tannins and their derivatives; dyes, pigments and other coloring matter; paints and varnishes (HS2 code 32); and cosmetics or toilet preparations (HS2 code 33); see Table 2.

HS2 code for Chemicals \& Allied Industries

Table 2

\begin{tabular}{|c|l|}
\hline HS2 code & \multicolumn{1}{c|}{ Name of the commodity group } \\
\hline 28 & $\begin{array}{l}\text { Inorganic chemicals; organic or inorganic compounds of precious metals, of rare-earth metals, } \\
\text { of radioactive elements or of isotopes }\end{array}$ \\
\hline 29 & Organic chemicals \\
\hline 30 & Pharmaceutical products \\
\hline 31 & Fertilizers \\
\hline 32 & $\begin{array}{l}\text { Tanning or dyeing extracts; tannins and their derivatives; dyes, pigments and other coloring matter; } \\
\text { paints and varnishes; putty and other mastics; inks }\end{array}$ \\
\hline 33 & Essential oils and resinoids; perfumery, cosmetic or toilet preparations \\
\hline 34 & $\begin{array}{l}\text { Soap, organic surface-active agents, washing preparations, lubricating preparations, artificial waxes, } \\
\text { prepared waxes, polishing or scouring preparations, candles and similar articles, modeling pastes, }\end{array}$ \\
\hline 35 & "dental waxes" and dental preparations with a basis of plaster \\
\hline 36 & Elbuminoidal substances; modified starches; glues; enzymes \\
\hline 37 & Photographic pyrotechnic products; matches; pyrophoric alloys; certain combustible preparations \\
\hline 38 & Miscellaneous chemical products \\
\hline
\end{tabular}

Source: State Customs Committee of the Republic of Uzbekistan (http://tarif.customs.uz/?lang=en_EN).

Commodity structure of chemical imports, 2019 (HS2), \%

Figure 3

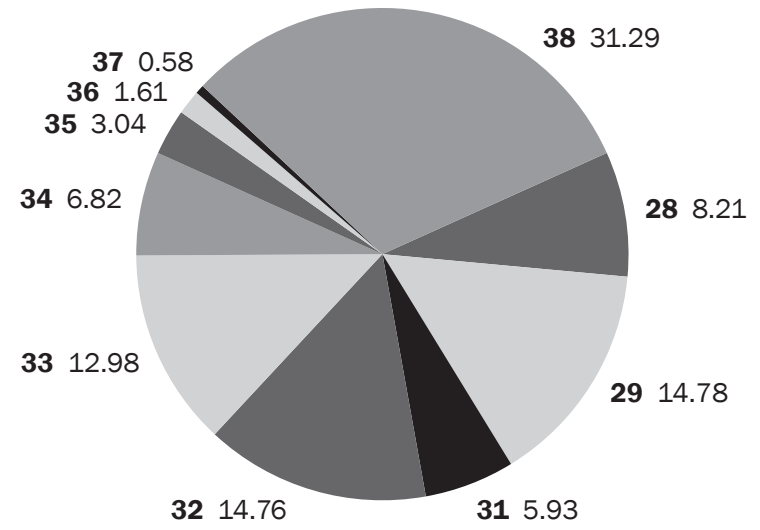

Source: ITC Trade Map. International Trade Centre.

The main volume of chemical products is imported from China, Russia, and Kazakhstan (see Figure 4). Uzbekistan's exports are mainly concentrated in fertilizers (HS code 31), which account for almost $67 \%$ of the industry's exports. As mentioned above, this is the only commodity group where Uzbekistan is a net exporter with a trade balance of 73.7 million $\mathrm{USD}^{29}$. The chemical sector is predominantly regional due to high transport costs. This fact is confirmed by the predominantly regional nature of imports and exports in countries around the world; Uzbekistan is not an exception. The main share of chemical products is exported to such countries of the region as Kazakhstan, Kyrgyzstan and Tajikistan ${ }^{30}$.

\footnotetext{
${ }^{29}$ ITC Trade Map. International Trade Centre.

${ }^{30}$ Ibidem.
} 
Geographic structure of chemical imports, 2019, \%

Figure 4

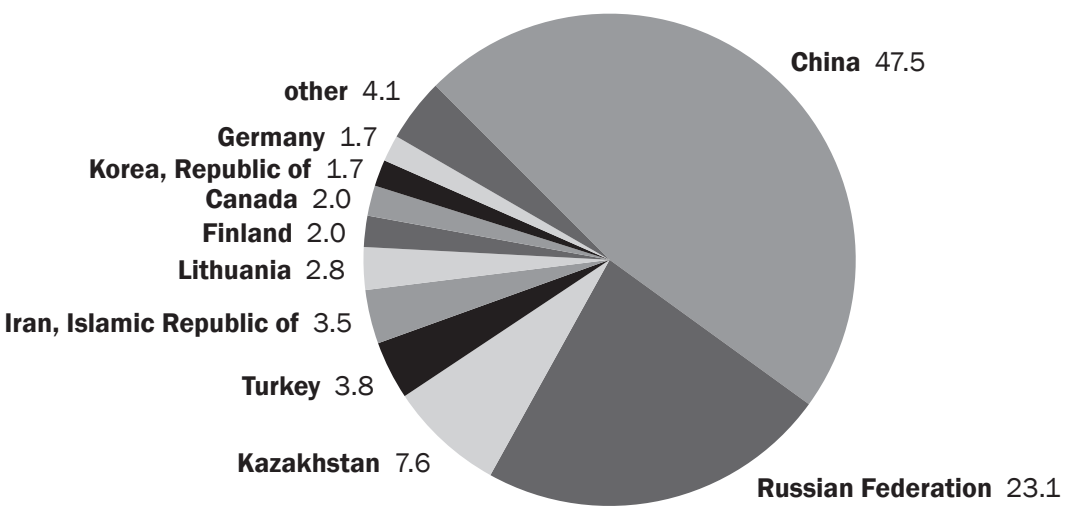

Source: ITC Trade Map. International Trade Centre.

Commodity structure of chemical exports, 2019 (HS2), \%

Figure 5

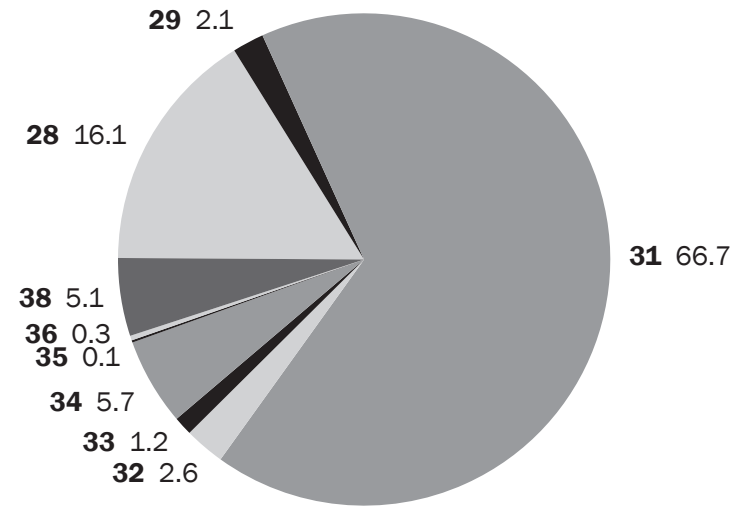

Source: ITC Trade Map. International Trade Centre.

The geographic structure of Uzbekistan's export of chemicals is shown in Figure 6. The bulk of exports are directed to countries with which Uzbekistan has an agreement on preferential trade. Recent improvements in relations with the closest neighbors have resulted in a significant increase in overall regional trade.

While in 2017 the growth in imports of chemicals amounted to $8.8 \%$, in 2018 it amounted to $23.2 \%$, sharply reacting to a decrease in average import duties from $6.0 \%$ to $1.3 \%$. A particularly sharp increase in imports in 2018 was observed in the group of fertilizer products $(156 \%)^{31}$, where import duties were substantially reduced ${ }^{32}$. In order to forecast the level of import tariffs in Uzbekistan upon accession to the WTO, the existing import tariffs of WTO countries - Uzbekistan's major trading partners - were compared (MFN tariffs, Figure 7).

${ }^{31}$ Ibidem.

${ }^{32}$ On amendments and additions to the Resolution of the President of the Republic of Uzbekistan dated June 29, 2018 No. PP-3818 "On measures to further streamline foreign economic activity and improve the system of customs and tariff regulation of the Republic of Uzbekistan." Norma, last modified October 2, 2019 (Russ.). Available at: https://static.norma.uz/official_texts/2019/\%D0\%9F\%D0\%9F-4470.pdf. 
Geographic structure of chemical exports, 2019, \%

Figure 6

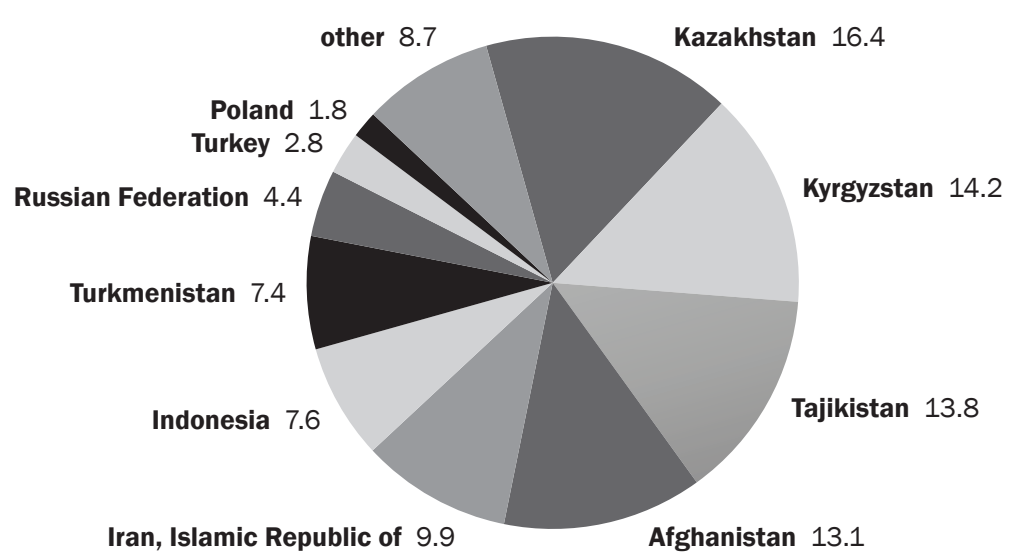

Source: ITC Trade Map. International Trade Centre.

Uzbekistan's import MFN tariffs for product groups 33, 34 and 36 turn out to be much higher than tariffs of the above-mentioned countries. However, tariffs for other groups of goods $(28,29,37$ and 38$)$ are lower or almost equal zero. In bilateral negotiation processes, countries like the EU and Turkey may put pressure on Uzbekistan to lower tariffs on commodity groups where the level is higher.

MFN tariffs applied by Uzbekistan

Figure 7 and its major trading partners on chemical products, $\%$

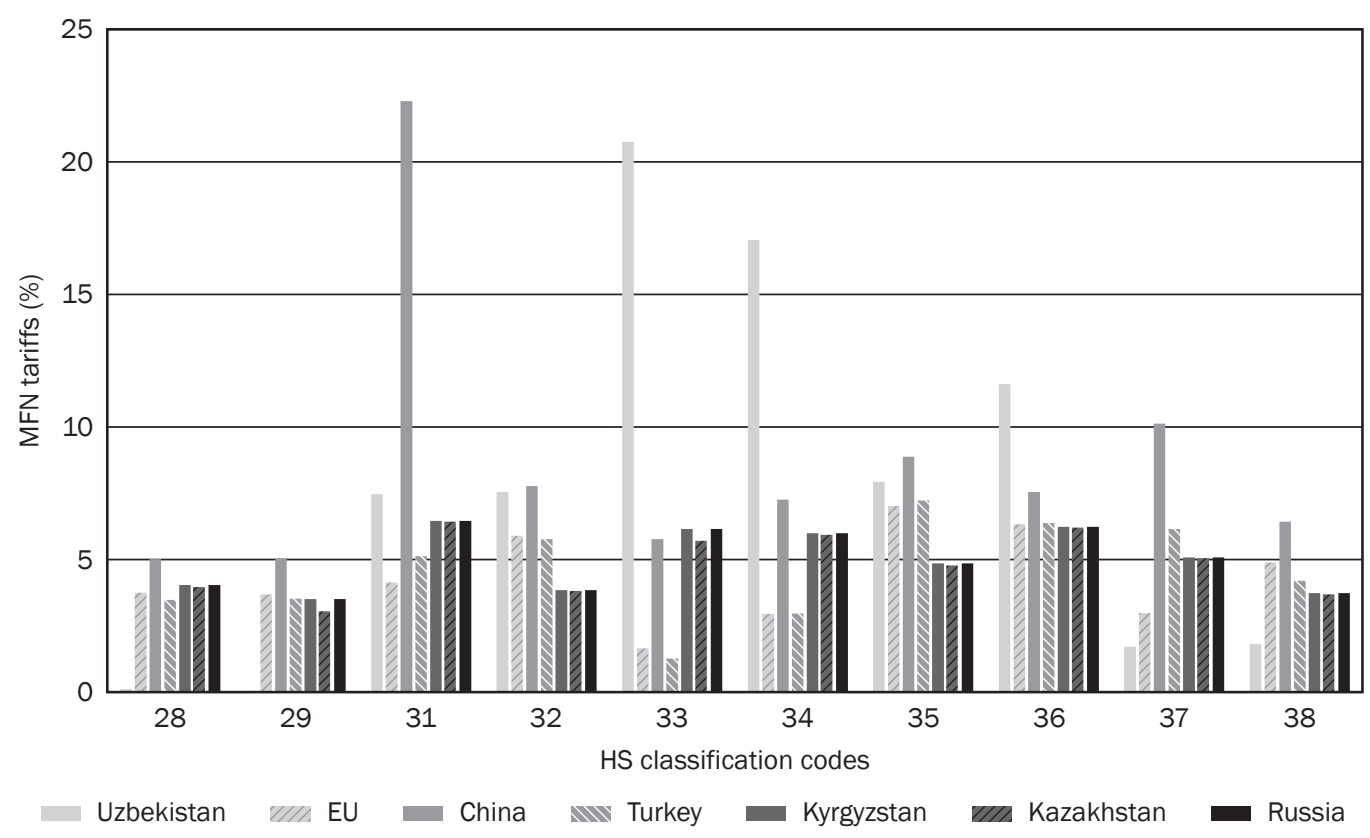

Source: ITC Aggregated Market Access Indicators. International Trade Centre.

According to Uzbekistan's legislation, MFN tariffs are reduced rates which apply in the case of an agreement on trade preferences with another country. For the rest of the world excluding 
the CISFTA, Azerbaijan, Georgia and Turkmenistan, a double rate applies ${ }^{33}$. The MFN tariff may be further decreased based on bilateral agreements, which is the case of Uzbekistan's major trading partners ${ }^{34}$.

Because of the predominantly regional nature of foreign trade in chemical products, most of the above-mentioned countries will be the main competitors for Uzbekistan. With regard to this fact, the average level of import duties in these countries is a more acceptable and likely option for Uzbekistan.

Another issue which may complicate the WTO accession process is that the customs system of Uzbekistan is characterized by the presence of exemptions for certain industries and enterprises where import duties payments are waived for them; this creates uneven conditions for producers in the market. Such conditions do not comply with the principles of the WTO. In accordance with the Agreement on Subsidies and Countervailing Measures of the WTO, benefits to individual enterprises and industries are classified as subsidies. They are either prohibited or subject to challenge if they cause negative effects to the interests of a WTO member country ${ }^{35}$. The possible abolition of these benefits upon accession to the WTO will have a fundamental impact on the budget.

Another example of discrimination is the excise tax application. For example, the group of goods "Lubricants" (HS code 3403) is subject to an excise tax of $5 \%$ on imports, but not on domestic production ${ }^{36}$. This approach is considered to be discrimination against imports under WTO rules and is not allowed. Uzbekistan will have to abolish or reduce to zero the excise tax imposed exclusively on imports upon joining the organization.

In order to predict the effects of Uzbekistan's accession to the WTO, we used the partial equilibrium model. To see the changes in the shares of different groups of countries we divided them into four groups:

(1) MFN countries according to Uzbekistan's agreements on trade preferences (47 countries); MFN rates are applied to goods originating in these countries;

(2) CISFTA countries (ten countries) where zero import tariff rates are applied; Azerbaijan, Georgia and Turkmenistan also fall into this group thanks to the FTA with Uzbekistan, but they are not included in the following tables due to their negligible share in chemical imports;

(3) non-MFN, non-CISFTA but WTO member countries for whom a double tariff rate is applied;

(4) non-MFN, non-CISFTA and non-WTO countries for whom a double tariff rate is applied.

Most trade of the country occurs with the MFN and CISFTA countries, which made up $97 \%$ of total trade in 2019. We considered two scenarios:

\section{Scenario 1}

We assume that the level of tariffs in Uzbekistan is more likely to decrease to about the level of neighboring countries. Therefore, it is assumed that the tariff rate will change from current rates to the average rate of the region; no other changes regarding import payments

\footnotetext{
${ }^{33}$ Customs Code of the Republic of Uzbekistan. National legislation database of the Republic of Uzbekistan.

${ }^{34}$ ITC Aggregated Market Access Indicators. International Trade Centre, accessed December 20, 2020. Available at: https://www.macmap.org/en/query/compare-market.

${ }^{35}$ Uruguay Round of Multilateral Trade Negotiations (1986-1994) - Annex 1 - Agreement on Subsidies and Countervailing Measures. WTO-GATT, accessed March 11, 2020. Available at: https://eur-lex.europa.eu/legalcontent/EN/TXT/?uri=CELEX\%3A21994A1223\%2814\%29.

${ }^{36}$ Law of the Republic of Uzbekistan on the State Budget of the Republic of Uzbekistan for 2020. Appendix 8. Rates of excise tax on excisable goods (services) produced (rendered) in the Republic of Uzbekistan. National legislation database of the Republic of Uzbekistan; Excise tax rates on excisable goods imported into the territory of the Republic of Uzbekistan. Complete legislation of Uzbekistan.
} 
are considered (VAT, excise tax, import duty payment exemptions and valuation methods stay the same). The assumed tariff rate remains unchanged if it is lower than the average rate in the region. Table 3 contains the input data for the partial equilibrium model.

Table 3

\section{Scenario 1: Input data for the partial equilibrium model}

\begin{tabular}{|c|c|c|c|c|c|c|c|}
\hline $\begin{array}{c}\text { HS2 } \\
\text { code }\end{array}$ & $\begin{array}{c}\text { Share in } \\
\text { imports }\end{array}$ & $\begin{array}{c}\text { Current tariff rate } \\
\text { for MFN countries } \\
\text { (\% of import value) }\end{array}$ & $\begin{array}{c}\text { Expected tariff rate } \\
\text { for MFN countries } \\
\text { (\% of import value) }\end{array}$ & $\begin{array}{c}\text { Change } \\
\text { in tariff } \\
\text { rate }\end{array}$ & $\begin{array}{c}\text { Import } \\
\text { demand } \\
\text { elasticity }\end{array}$ & $\begin{array}{c}\text { Export } \\
\text { supply } \\
\text { elasticity }\end{array}$ & $\begin{array}{c}\text { Elasticity } \\
\text { of substi- } \\
\text { tution* }\end{array}$ \\
\hline 28 & 8.21 & 0.11 & 0.11 & 0.0 & 1.05 & 99 & 6.6 \\
\hline 29 & 14.78 & 0.04 & 0.04 & 0.0 & 1.59 & 99 & 6.6 \\
\hline 31 & 5.93 & 7.47 & 7.47 & 0.0 & 4.03 & 99 & 6.6 \\
\hline 32 & 14.76 & 7.55 & 5.40 & -2.15 & 1.05 & 99 & 6.6 \\
\hline 33 & 12.98 & 20.74 & 4.81 & -15.9 & 0.94 & 99 & 6.6 \\
\hline 34 & 6.82 & 17.05 & 5.35 & -11.7 & 1.23 & 99 & 6.6 \\
\hline 35 & 3.04 & 7.93 & 7.93 & 0.0 & 0.81 & 99 & 6.6 \\
\hline 36 & 1.61 & 11.62 & 6.49 & -5.3 & 3.38 & 99 & 6.6 \\
\hline 37 & 0.58 & 1.71 & 1.71 & 0.0 & 1.58 & 99 & 6.6 \\
\hline 38 & 31.29 & 1.81 & 1.81 & 0.0 & 1.18 & 99 & 6.6 \\
\hline
\end{tabular}

Note: World Integrated Trade Solution' "SMART Simulation Tool” was used to process the input data.

Sources: authors' calculations based on ITC Aggregated Market Access Indicators; * Hertel T. et al., 2007, pp. 611-635.

Table 4 shows that the overall import of Uzbekistan would increase by 21.2 million USD mainly because of decreasing import tariffs. But it would not affect different group of countries equally. Imports from CISFTA countries would drop, as expected, since the tariff reduction for other WTO countries would dilute their relative import advantage. The share of the CISFTA countries would decrease from $27.4 \%$ to $21.6 \%$ while the share of the MFN countries would rise. The WTO member states who were neither the MFN nor CISFTA countries would feel stronger relief in import tariffs, and their imports to Uzbekistan would increase by $72 \%$. Imports from the non-CISFTA, non-MFN and non-WTO countries could improve slightly, since tariffs for them would generally decrease even if a double tariff rate were imposed on their imports.

Table 4

Scenario 1: Import changes for groups of countries

\begin{tabular}{|l|c|c|c|c|c|c|}
\hline \multirow{2}{*}{} & \multicolumn{2}{|c|}{$\begin{array}{c}\text { Imports } \\
\text { before accession }\end{array}$} & \multicolumn{2}{|c|}{$\begin{array}{c}\text { Imports } \\
\text { after accession }\end{array}$} & Growth & $\begin{array}{c}\text { Import } \\
\text { change }\end{array}$ \\
\cline { 2 - 7 } & Million USD & Share (\%) & Million USD & Share (\%) & $\%$ & Million USD \\
\hline $\begin{array}{l}\text { MFN countries for Uzbekistan } \\
\text { (47 countries) }\end{array}$ & 754.7 & 69.8 & 824.7 & 74.8 & 9.3 & 70.0 \\
\hline CISFTA countries (10 countries) & 296.8 & 27.4 & 238.3 & 21.6 & -19.7 & -58.5 \\
\hline Non-MFN, non-CISFTA but member of WTO & 10.8 & 1.0 & 18.6 & 1.7 & 72.4 & 7.8 \\
\hline Non-MFN, non-CISFTA non-WTO & 19.5 & 1.8 & 21.5 & 1.9 & 10.2 & 2.0 \\
\hline Total & $1,081.8$ & 100.0 & $1,103.1$ & 100.0 & 2.0 & 21.2 \\
\hline
\end{tabular}

Source: authors' calculations.

Table 5 shows the expected changes in tariff revenues, imports and consumer welfare for each product group. Our results show that budget tariff revenues would fall sharply, by $43 \%$, reflecting the overwhelming effect of a decrease in tariffs over a small increase in imports, by only $2 \%$. An insignificant increase in imports would have a small but positive effect on consumer welfare. 


\section{Scenario 1: Expected changes in tariff revenues, imports and consumer welfare}

\begin{tabular}{|c|c|c|c|c|c|}
\hline \multirow{2}{*}{$\begin{array}{c}\text { HS2 } \\
\text { code }\end{array}$} & \multicolumn{2}{|c|}{ Change in budget tariff revenue } & \multicolumn{2}{|c|}{ Expected import change } & \multirow{2}{*}{$\begin{array}{c}\text { Change in } \\
\text { consumer welfare } \\
\text { (million USD) }\end{array}$} \\
\cline { 2 - 5 } & Million USD & $\%$ & Million USD & $\%$ & 0.0 \\
\hline 28 & 0.00 & -3.1 & 0.0 & 0.0 & 0.0 \\
\hline 29 & 0.00 & -2.4 & 0.0 & 0.0 & 0.0 \\
\hline 31 & 0.00 & -0.5 & 0.0 & 0.1 & 0.2 \\
\hline 32 & -2.62 & -25.6 & 2.9 & 1.8 & 1.2 \\
\hline 33 & -13.19 & -64.2 & 12.3 & 8.7 & 0.5 \\
\hline 34 & -4.68 & -56.3 & 6.0 & 8.1 & 0.0 \\
\hline 35 & 0.00 & -0.1 & 0.0 & 0.0 & 0.0 \\
\hline 36 & 0.00 & -15.2 & 0.0 & 0.2 & 0.0 \\
\hline 37 & -0.01 & -5.9 & 0.0 & 0.2 & 0.0 \\
\hline 38 & -0.03 & -0.6 & 0.0 & 0.0 & 1.8 \\
\hline Total & -20.5 & -43.0 & 21.2 & 2.0 & \\
\hline
\end{tabular}

Source: authors' calculations.

Overall, the negative effects of lowering the tariffs rates upon joining the WTO, resulting in a sharp fall in budget revenues, may seem to outweigh the positive effects in consumer welfare. On the other hand, Scenario 1 does not take into account wider policy changes associated with the actual WTO accession. Therefore, in Scenario 2 we consider further necessary liberalization in Uzbekistan's trade policy.

\section{Scenario 2}

Along with import tariff rates reduction, we assume that the country will abolish all import duty payment practices not complying with the WTO rules. The main distorting factor, as discussed above, is the exemptions given to certain national companies or industries concerning import tariff, VAT and excise tax payments. Another one is the valuation method. In Uzbekistan, the basis for applying tariffs is prices quoted in the Import Price Bulletin of the State Customs Committee, which are usually higher than declared import prices. The gap between the prices can vary from 10 to $30 \%$ making the import payments much higher than expected ${ }^{37}$. Due to these distortions, the nominal protection rate does not reflect the actual situation. Therefore, we calculated the actual rate of protection as the ratio of collected import tariff, VAT and excise tax payments to import value (based on the Import Price Bulletin) from the database of the State Customs Committee, considering the existing exemptions. The main input data are provided in Table 6 . It is evident that the nominal protection rate differs from the actual protection rate significantly. We therefore used the actual protection rate as the current rate in order to see the actual changes in revenues from import duties after they are adjusted to the regional level. The expected protection rate is calculated as the sum of regional average import tariff rate plus VAT, with a $0 \%$ excise tax due to its nature of a discriminative practice. Import excise taxes are currently applied to product groups 32, 33 , and $34^{38}$. We also assume the abolition of exemptions provided to certain companies. We used the same elasticities as in Scenario 1.

\footnotetext{
${ }^{37}$ Import Price Bulletin. Open Data Portal of the Republic of Uzbekistan, accessed February 14, 2021. Available at: https://data.gov.uz/en/datasets/7; State Customs Committee of the Republic of Uzbekistan, 2019.

${ }^{38}$ Excise tax rates on excisable goods imported into the territory of the Republic of Uzbekistan. Complete legislation of Uzbekistan.
} 


\section{Scenario 2: Input data for the partial equilibrium model}

\begin{tabular}{|c|c|c|c|c|c|}
\hline $\begin{array}{c}\text { HS2 } \\
\text { code }\end{array}$ & $\begin{array}{c}\text { Share } \\
\text { in imports }\end{array}$ & $\begin{array}{c}\text { Nominal } \\
\text { protection rate (\%) }\end{array}$ & $\begin{array}{c}\text { Actual } \\
\text { protection rate (\%) }\end{array}$ & $\begin{array}{c}\text { Expected } \\
\text { protection rate (\%) }\end{array}$ & $\begin{array}{c}\text { Change in protection rate } \\
\text { (actual - expected) }\end{array}$ \\
\hline 28 & 8.21 & 15.1 & 15.2 & 15.1 & -0.1 \\
\hline 29 & 14.78 & 15.0 & 10.6 & 15.0 & 4.4 \\
\hline 31 & 5.93 & 22.5 & 0.5 & 22.5 & 21.9 \\
\hline 32 & 14.76 & 22.6 & 15.8 & 20.4 & 4.7 \\
\hline 33 & 12.98 & 35.9 & 25.7 & 19.8 & -5.9 \\
\hline 34 & 6.82 & 32.2 & 24.0 & 20.3 & -3.6 \\
\hline 35 & 3.04 & 22.9 & 20.3 & 22.9 & 2.6 \\
\hline 36 & 1.61 & 26.6 & 34.2 & 21.5 & -12.8 \\
\hline 37 & 0.58 & 16.7 & 13.4 & 16.7 & 3.3 \\
\hline 38 & 31.29 & 16.8 & 8.2 & 16.8 & 8.6 \\
\hline
\end{tabular}

Explanatory notes: Nominal protection rate includes: current tariff rates, VAT, import-specific excise taxes, no import duty payment exemptions; valuation method: invoice prices (declared prices). Actual protection rate includes: current tariff rates, VAT, import-specific excise taxes, import duty payment exemptions; valuation method: Import Price Bulletin prices. Expected protection rate includes: tariff rates (lowered to regional level), VAT, 0 \% importspecific excise tax, no import duty payment exemptions; valuation method: invoice prices (declared prices).

Sources: authors' calculations based on ITC Aggregated Market Access Indicators; Customs duty rates and import volumes, State Customs Committee of the Republic of Uzbekistan. Data set, 2019.

The results of Scenario 2 for individual groups of countries are shown in Table 7 . The overall effect of an expected trade policy change on imports is negative, which can be explained by the greater negative effect of abolition of exemptions over comparatively smaller total effects of tariffs reduction, elimination of discriminating excise taxes for some product groups and using actual declared import prices instead of Import Price Bulletin prices.

The CISFTA countries and the non-MFN, non-CISFTA non-WTO countries would experience the most negative effects, with the least negative impact on MFN countries; their imports would decrease by $10.7 \%, 12.4 \%$ and $6.1 \%$ respectively, although without any major changes in their import shares. WTO member countries (non-MFN, non-CISFTA) would benefit from the changes and their imports would rise. For these countries the positive effect of a decrease from double tariff rates to lowered tariff rates seems to be outweighing the negative effect of the exemptions abolition.

Table 7

Scenario 2: Import changes for individual group of countries

\begin{tabular}{|l|c|c|c|c|c|c|}
\hline & \multicolumn{2}{|c|}{$\begin{array}{c}\text { Imports } \\
\text { before accession }\end{array}$} & \multicolumn{2}{|c|}{$\begin{array}{c}\text { Imports } \\
\text { after accession }\end{array}$} & Growth & $\begin{array}{c}\text { Import } \\
\text { change }\end{array}$ \\
\cline { 2 - 7 } & Million USD & Share (\%) & Million USD & Share (\%) & $\%$ & Million USD \\
\hline $\begin{array}{l}\text { MFN countries for Uzbekistan } \\
\text { (47 countries) }\end{array}$ & 754.7 & 69.8 & 708.9 & 70.7 & -6.1 & -45.8 \\
\hline CISFTA countries (10 countries) & 296.8 & 27.4 & 265.1 & 26.4 & -10.7 & -31.7 \\
\hline Non-MFN non-CISFTA but member of WTO & 10.8 & 1.0 & 11.5 & 1.2 & 7.1 & 0.8 \\
\hline Non-MFN non-CISFTA non-WTO & 19.5 & 1.8 & 17.1 & 1.7 & -12.4 & -2.4 \\
\hline Total & 1081.8 & 100.0 & 1002.6 & 100.0 & -7.3 & -79.2 \\
\hline
\end{tabular}

Source: authors' calculations.

Table 8 shows impacts on budget revenues, imports and consumer welfare for each product group. Budget revenues from import tariffs, VAT and $0 \%$ excise taxes increase by $20.8 \%$ for chemicals in general, but not evenly across product groups, and in some cases the results are negative. Budget revenues as a whole increase because the effect of abolished exemptions 
outweighs the reduced imports. In other words, the budget will receive import fees that were waived before. A significant decrease in imports is a consequence of abolishing the exemptions (imports became more expensive for importers) and pulls the consumer welfare to negative 7.58 million USD.

Table 8

\section{Scenario 2: Expected changes in tariff revenues, imports and consumer welfare}

\begin{tabular}{|c|c|c|c|c|c|}
\hline \multirow{2}{*}{$\begin{array}{c}\text { HS2 } \\
\text { code }\end{array}$} & \multicolumn{2}{|c|}{$\begin{array}{c}\text { Change in budget revenues from tariff, } \\
\text { VAT and excise tax }\end{array}$} & \multicolumn{2}{c|}{ Expected import change } & \multirow{2}{*}{$\begin{array}{c}\text { Change in consumer } \\
\text { welfare (million USD) }\end{array}$} \\
\cline { 2 - 5 } & Million USD & $\%$ & Million USD & $\%$ & 0.01 \\
\hline 28 & -0.07 & -0.5 & 0.08 & 0.1 & -1.30 \\
\hline 29 & 5.52 & 32.6 & -10.12 & -6.3 & -3.15 \\
\hline 31 & 3.20 & 996.9 & -40.68 & -63.4 & -1.12 \\
\hline 32 & 5.79 & 24.0 & -6.49 & -4.1 & 1.29 \\
\hline 33 & -6.88 & -20.4 & 6.09 & 4.3 & 0.35 \\
\hline 34 & -1.20 & -7.8 & 1.75 & 2.4 & -0.09 \\
\hline 35 & 0.45 & 6.9 & -0.45 & -1.4 & 0.28 \\
\hline 36 & -0.33 & -10.2 & 1.69 & 9.7 & -0.04 \\
\hline 37 & 0.16 & 18.6 & -0.28 & -4.5 & -3.80 \\
\hline 38 & 23.01 & 82.9 & -30.80 & -9.1 & -7.58 \\
\hline Total & 29.7 & 20.8 & -79.21 & -7.3 & \\
\hline
\end{tabular}

Source: authors' calculations.

The decrease in imports should normally result in lower budget revenues, but in our case the effect of exemptions abolishment is so great that it causes a positive net change in budget revenues. With respect to the trade deficit, lower imports are considered favorable, although it reduces competition in the country's chemical industry. Scenario 2 demonstrates that import tariff reduction along with substantial trade policy changes can result in a net positive effect on the economy. Allee and Scalera [Allee T.L., Scalera J.E., 2012] or Dutt [Dutt P., 2020] linked significant policy changes during the accession process to considerable benefits concerning trade flows. In our case, benefits of WTO accession in the short term would rather involve the elimination of trade distortions caused by discriminative measures. Scenario 2 is obviously the more realistic one because the WTO will expect Uzbekistan to abolish many practices used to help particular sectors and producers, as pointed out by Pomfret [Pomfret R., 2020]. Such a process will be helpful in creating a fairer, market-oriented environment. The authors of the study on predicted consequences of the WTO accession for the ultra-protected automobile industry in Uzbekistan also conclude that removing state interventions (in this case a monopoly position of a major domestic car producer) will be beneficial and improve the competitive environment in the country [Umirdinov A., Turakulov V., 2019].

\section{CONCLUSIONS}

Uzbekistan has set on a challenging journey of liberalizing its economy including foreign trade. The impact of the first reforms on trade flows is already evident, reflected particularly in increased imports. The WTO accession process will require intense negotiations regarding not only tariff rates but also eliminating practices that do not comply with the WTO rules. The expected changes include reducing import-specific excise taxes to zero and abolishing exemptions for companies concerning import duties payments. In our paper we focused on the chemical industry trade and illustrated two situations. The first scenario involved only the reduction of tariff rates, whereas the second one also included eliminating all discriminative practices in import creating unequal conditions. The two scenarios gave dissimilar results. While in the first case the outcome was negative in terms of budget revenues and slightly positive thanks to an insignificant increase in imports and consumer welfare, the second 
case had a different result: budget revenues increased, mainly due to the abolition of exemptions, and imports dropped by $7.3 \%$. Considering that Uzbekistan has been facing a negative trade balance in recent years, the reduction of the trade deficit is desirable. On the other hand, increased foreign competition would serve as a beneficial motivation for improving the obsolete production facilities. Increasing the technological competitiveness and productivity of Uzbekistan's chemical industry is crucial since the energy and material consumption of local production is high. The negatives, at the same time, will be outweighed by creating a fairer, more competitive environment.

If Uzbekistan stays outside the WTO, discriminative practices and protectionist measures will remain and continue to distort the economy. Removing these barriers will create fair, equal conditions for all market players. Considering these benefits, WTO membership will undoubtedly contribute to Uzbekistan's liberalization efforts and help the country to become a full-blooded member of the global economic community.

\section{References}

Allee T.L., Scalera J.E. (2012). The Divergent Effects of Joining International Organizations: Trade Gains and the Rigors of WTO Accession." International Organization, vol. 66, iss. 2 pp. 243-276. Available at: https:// doi.org/10.1017/S0020818312000082.

Abaturov V., Rizaeva. Z. (2020). Customs Reforms. Interview with M. Azimov. Review.uz, no. 5, pp. 49-55. Available at: https://review.uz/journals/05-245-2020.

Dutt P. (2020). The WTO is not passé. European Economic Review, vol. 128, article 103507. Available at: https://doi.org/10.1016/j.euroecorev.2020.103507.

Eicher T.S., Henn C. (2011). In search of WTO trade effects: Preferential trade agreements promote trade strongly, but unevenly. Journal of International Economics, vol. 83, iss. 2 pp. 137-153. Available at: https://doi. org/10.1016/j.jinteco.2010.12.002

Hertel T., Hummels D., Ivanic M. et al. (2007). How confident can we be of CGE-based assessments of Free Trade Agreements? Economic Modelling, vol. 24, iss. 4, pp. 611-635. Available at: https://doi.org/10.1016/ j.econmod.2006.12.002.

World Bank Group, International Finance Corporation, 2018. Creating markets in Uzbekistan: from stabilization to competitiveness. Available at: http://invest-in-uzbekistan.org/wp-content/uploads/4_6004767272294416554.pdf.

Abaturov V., Rizaeva Z. Chemical Industry Reform Trajectory. Interview with Z. Mirzamakhmudov. Review.uz, March 16, 2020. Available at: https://review.uz/post/traektoriya-reform-ximproma.

Mukhamedov D., Shipkova O. (2017). Chemical Industry of the Republic of Uzbekistan: Major Obstacles of the Industry Development. Advances in chemistry and chemical technology, vol. 31, no. 14, pp. 25-27. Available at: https://muctr.ru/upload/iblock/9c3/9c3bb1cf5c074173b13b8a6e9ca49b2f.pdf.

Pomfret R. (2020). Uzbekistan and the World Trade Organization. Silk Road: A Journal of Eurasian Development. vol. 2, iss. 1, pp. 54-61. Available at: https://doi.org/10.16997/srjed.35.

Rose A.K. (2004). Do we really know that the WTO increases trade? American Economic Review, vol. 94, no. 1 pp. 98-114. Available at: https://www.aeaweb.org/articles?id=10.1257/000282804322970724.

Rose A.K. (2010). The Effect of Membership in the GATT/WTO on Trade: Where Do We Stand?" In Is the World Trade Organization Attractive Enough for Emerging Economies? Critical Essays on the Multilateral Trading System. Ed. by Z. Drabek, pp. 195-216. London: Palgrave Macmillan. Available at: https://doi.org/10.1057/9780230250826_8.

Subramanian A., Wei Shang-Jin (2007). The WTO promotes trade, strongly but unevenly." Journal of International Economics vol. 72, iss. 1, pp. 151-175. Available at: https://doi.org/10.1016/j.jinteco.2006.07.007.

Umirdinov A., Turakulov V. (2019). The Last Bastion of Protectionism in Central Asia: Uzbekistan's Auto Industry in post-WTO Accession. Trade, Law \& Development, vol. 11, no. 2, pp. 301-333.

\section{Information about the authors}

Lea Melnikovová, Senior Lecturer, Department of International Business, Metropolitan University Prague, Prague, Czech Republic (corresponding author)

Shukhrat Shadmanov, Candidate of Economic Sciences, Leading Lecturer, School of Business and Management, Management Development Institute of Singapore in Tashkent, Tashkent, Uzbekistan

Sergey Voronin, Doctor of Economic Sciences, Professor, Department of Finance and Credit, Tashkent Branch of Plekhanov Russian University of Economics, Tashkent, Uzbekistan

Bobur Qoraboev, Chief Specialist, Department of Improvement Taxes and Customs Tariff Policy, Institute for fiscal studies under the Ministry of finance the Republic of Uzbekistan, Tashkent, Uzbekistan 
Article submitted November 3, 2021

Approved after reviewing January 10, 2022

Accepted for publication February 4, 2022

https://doi.org/10.31107/2075-1990-2022-1-39-55

\section{Аиберализация торговой политики Узбекистана. Прогнозируемые последствия вступления в ВТО по торговле продукцией химической промышленности}

иеа Мельниковова, старший преподаватель Аепартамента международного бизнеса Столичного университета Праги, Прага 10000, Чешская Республика (автор-корреспондент)

E-mail: lea.melnikovova@mup.cz, ORCID: 0000-0003-0283-8483

Шухрат Шадманов, кандидат экономических наук, ведущий преподаватель Школы бизнеса и менеджмента Сингапурского института развития менеджмента в Ташкенте, Ташкент 100185, Республика Узбекистан

E-mail: shshadmanov@mdis.uz, ORCID: 0000-0002-0324-6247

Сергей Воронин, Аоктор экономических наук, профессор кафедры финансов и кредита Ташкентского филиала РЭУ им. Г. В. Плеханова, Ташкент 100164, Республика Узбекистан

E-mail: Sergey_voronin63@yahoo.com, ORCID: 0000-0003-2288-8365

Бобур Корабоев, главный специалист Института бюджетно-налоговых исследований при Министерстве финансов Республики Узбекистан, Ташкент 100052, Республика Узбекистан

E-mail: BKoraboev@ifs.mf.uz, ORCID: 0000-0003-4051-982X

\section{Аннотация}

Эта статья посвящена недавним реформам во внешней торговой политике Узбекистана и процессу вступления страны во Всемирную торговую организацию. Особое внимание уделяется торговме продукцией химической промышленности. С использованием модели частичного равновесия выявляются ожидаемые изменения импорта химических веществ, Аоходов бюджета и благосостояния потребителей. Рассмотрены Ава сценария: простое снижение тарифов или отмена специфической Аля страны практики дискриминации при импорте. Результаты показывают, что в первом случае импорт химической продукции и благосостояние потребителей несколько увеличатся, а Аоходы бюАжета снизятся. Во втором случае исход будет Аругим: Аоходы бюджета значительно вырастут, импорт и благосостояние потребителей снизятся. Во втором случае мы пришли к выводу, что негативный эффект будет компенсирован созданием более справедливой и конкурентной среды за счет устранения дискриминационных практик, таких как акцизы на импорт и освобождение от уплаты импортных пошлин Аля государственных компаний.

Ключевые слова: Всемирная торговая организация, соглашение о свободной торговле, классификация гармонизированной системы, режим наибольшего благоприятствования, химическая промышленность и смежные отрасли, модель частичного равновесия, тарифные доходы, благосостояние потребителей

JEL: E21, F13, F14, F15, F17

Аия цитирования: Melnikovová L., Shadmanov Sh., Voronin S., Qoraboev B. Uzbekistan's Trade Policy Liberalization. Predicted Impact of WTO Accession on Chemical Industry Trade. Financial Journal, 2022, vol. 14, no. 1, pp. 39-55.

https://doi.org/10.31107/2075-1990-2022-1-39-55.

(C) Melnikovová L., Shadmanov Sh., Voronin S., Qoraboev B., 2022 